\title{
Pengaruh Supervisi Kepala Sekolah dan Motivasi Kerja Guru Terhadap Kinerja Guru
}

\author{
Yopi Aprida ${ }^{\bowtie 1}$, Happy Fitria ${ }^{2}$, Nurkhalis ${ }^{3}$ \\ (1) Sekolah Menengah Pertama Negeri 4 Prabumulih
}

$(2,3)$ Universitas PGRI Palembang

$\triangle$ Corresponding author

[apridayopi@gmail.com]

\begin{abstract}
Abstrak
Penelitian ini bertujuan untuk mengetahui pengaruh supervisi kepala sekolah dan motivasi kerja guru secara bersama-sama terhadap kinerja guru di SMP Negeri se-Kecamatan Prabumulih Barat. Populasi penelitian ini adalah guru pada SMP Negeri se-Kecamatan Prabumulih Barat sebanyak 104 orang yang digunakan untuk sampel. Data dikumpulkan dengan kuesioner menggunakan skala likert, dianalisis dengan menggunakan teknik korelasi dan regresi dengan menggunakan program Statistical Package For Social Science (SPSS) versi 22.0 dan Manual. Penelitian ini menemukan bahwa 1) ada pengaruh supervisi kepala sekolah terhadap kinerja guru di SMP Negeri Se Kecamatan Prabumulih Barat sebesar 52,6\% sisanya 47,4\% dipengaruhi oleh faktor lain yang bukan menjadi variabel dalam penelitian ini. 2) pengaruh motivasi kerja guru terhadap kinerja guru di SMP Negeri Se Kecamatan Prabumulih Barat sebesar 46,2\% sisanya 53,8\% dipengaruhi oleh faktor lain yang bukan menjadi variabel dalam penelitian ini 3) ada pengaruh supervisi kepala sekolah dan motivasi kerja guru secara bersama-sama terhadap kinerja guru di SMP Negeri se-Kecamatan Prabumulih Barat, sebesar $58,5 \%$ sisanya $41,5 \%$ dipengaruhi oleh faktor lainnya yang tidak termaksud variable variabel pada penelitian ini.
\end{abstract}

Kata Kunci: Supervisi Kepala Sekolah; Motivasi Kerja; Kinerja Guru

\begin{abstract}
This study determined the effect of principal supervision and teacher work motivation together on the performance of teachers in SMP Negeri all Prabumulih Barat District. The population of this study were 104 teachers at State Junior High Schools in West Prabumulih Subdistrict, who were used for the sample. The data were collected by means of a questionnaire using a Likert scale, analyzed using correlation and regression techniques using the Statistical Package for Social Science (SPSS) version 22.0 and Manual. This study found that 1) there was an effect of school principal supervision on the performance of teachers in SMP Negeri Se Prabumulih Barat of 52.6\%, the remaining $47.4 \%$ was influenced by other factors which were not variables in this study. 2) the effect of teacher work motivation on teacher performance in SMP Negeri Se Prabumulih Barat District is $46.2 \%$, the remaining $53.8 \%$ is influenced by other factors that are not variables in this study 3 ) there is an effect of principal supervision and teacher work motivation together the same as the performance of teachers in State Junior High Schools in West Prabumulih Subdistrict, $58.5 \%$, the remaining $41.5 \%$ is influenced by other factors which are not included in the variable variables in this study.
\end{abstract}

Keyword: Principal supervision; work motivation; teacher performance.

\section{PENDAHULUAN}

Pendidikan pada hakikatnya merupakan hal yang tidak dapat dipisahkan dari kehidupan manusia yang selalu ingin berkembang dan berubah. Dalam pasal 1 ayat 1 UU RI No. 20 Tahun 2003 tentang Sistem Pendidikan Nasional disebutkan bahwa pendidikan adalah usaha sadar dan terencana untuk mewujudkan suasana belajar dan proses pembelajaran agar peserta didik secara aktif mengembangkan potensi dirinya untuk memiliki kekuatan spiritual keagamaan, pengendalian diri, kepribadian, kecerdasan, akhlak mulia, serta keterampilan yang diperlukan dirinya, masyarakat, bangsa dan negara.

Mutu pendidikan yang baik akan menghasilkan sumber daya manusia yang baik pula. Tujuan dari pendidikan dan pengajaran tidak terlepas dari adanya guru yang memiliki kompetensi optimal dalam dunia pendidikan. Guru tidak semata hanya mendidik, melainkan juga mengajar dan melatih. Guru dituntut memiliki kemampuan dan kompetensi yang baik agar tugas dan tanggung jawabnya dapat terlaksana dengan baik pula. Pencapaian kompetensi guru yang sesuai dengan standar kualifikasi akademik sehingga kinerja para guru sesuai dengan yang ditetapkan Permendiknas. Standar kualifikasi akademik menjadi dasar pendidikan 
minimum bagi guru pada suatu instansi kependidikan. Kualitas pendidikan merupakan kebutuhan sekaligus tuntutan yang hakiki untuk mencapai tujuan pendidikan.

Guru yang dapat melaksanakan tugas dan tanggung jawabnya dengan baik, dapat diartikan bahwa guru memiliki kinerja yang baik pula. Hal ini sesuai dengan pendapat Saondi (2010: 20) mengenai kinerja yang menyebutkan kinerja merupakan tingkat keberhasilan seseorang atau kelompok orang dalam melaksanakan tugas dan tanggung jawabnya serta kemampuan untuk mencapai tujuan dan standar yang telah ditetapkan. Oleh karena itu, guru sebagai pengemban tugas dan tanggung jawab keberhasilan tujuan pembelajaran diharuskan memiliki kinerja yang baik dan optimal agar tujuan dari pembelajaran dapat tercapai sepenuhnya. Kinerja guru yang optimal berawal dari penguasaan guru dalam kompetensi-kompetensi dasar yang harus dimiliki oleh seorang guru pada umumnya, yang kemudian berbekal pengalaman mengajar dan belajar akan menjadikan seorang guru matang dalam penguasaan kompetensi-kompetensi tersebut. Sehingga pengoptimalisasian kinerja guru dalam pembelajaran dipastikan dapat menunjang dan memiliki pengaruh yang besar bagi keberhasilan pembelajaran.

Pada dasarnya guru memiliki potensi yang cukup tinggi untuk berkreasi dan meningkatkan kinerja, namun banyak faktor yang menghambat mereka dalam mengembangkan berbagai potensinya secara optimal. Oleh karena itu sangat dirasakan perlunya pembinaan yang kontinu dan berkesinambungan dengan program yang terarah dan sistematis terhadap para guru dan personel sekolah. Kepala Sekolah mempunyai peranan yang sangat penting dalam mengkoordinasikan, sehingga memerlukan tingkat koordinasi yang tinggi. Oleh sebab itu kepala sekolah yang berhasil, mampu mewujudkan tujuan sekolah, serta tujuan dari para individu yang ada dalam lingkungan sekolah, harus memahami dan menguasai peranan organisasi dan hubungan kerja sama antara individu.

Kepala sekolah sebagai supervisor harus diwujudkan dalam kemampuan menyusun, dan melaksanakan program supervisi pendidikan, serta memanfaatkan hasilnya (Mulyasa, 2007). Supervisi kepala sekolah merupakan suatu proses yang dirancang secara khusus untuk membantu para guru dan supervisor agar dapat menggunakan pengetahuan dan keterampilannya dalam memberikan layanan kepada orang tua peserta didik dan sekolah (Wahyudi, 2009).

Faktor lain yang juga mempengaruhi kinerja guru yaitu motivasi kerja. Kebutuhan yang mendorong perbuatan ke arah suatu tujuan tertentu yang menimbulkan motif atau pemberian motif, menjadikan motivasi kerja merupakan sesuatu yang menimbulkan semangat atau dorongan kerja (Anoraga, 2006). Adanya motivasi kerja pada diri guru juga ikut mempengaruhi tinggi atau rendahnya kinerja yang dimiliki oleh guru, sehingga dengan adanya motivasi yang tinggi maka kinerja guru dapat dicapai secara optimal.

Berdasarkan pendapat tersebut, maka dapat disimpulkan bahwa supervii kepala sekolah dan motivasi kerja sebagai sesuatu yang kompleks, sehingga dapat berpengaruh terhadap persoalan gejala kejiwaan dan emosi, untuk kemudian melakukan sesutau. Motivasi kerja dan pembinaan atau supervisi memegang peranan penting dalam meingkatkan kinerja guru untuk dapat memaksimalkan hasil pemeblajaran dengan harapan mencapai tujuan yang ingin dicapai. Oleh sebab itu, peneliti ingin mengkaji lebih dalam secara ilmiah apakah supervisi dan motivasi kerja berpengaruh terhadap kinerja guru di SMP se-Kecamatan Prabumulih Barat.

Menurut Wilis (2001) kegiatan supervisi pada prinsipnya merupakan kegiatan membantu dan melayani guru agar diperoleh guru yang lebih bermutu yang selanjutnya diharapkan terbentuk situasi proses belajar mengajar yang lebih baik dalamrangka mencapai tujuan pendidikan. Menurut Harapan (2020) supervisi adalah bantuan yang diberikan supervisor kepada guru agar mengalami pertumbuhan secara maksimal dan integral baik profesi maupun pribadinya.

Menurut Fitria (2020) bahwa tujuan supervisi akademik adalah melakukan pembinaan khususnya kepada guru agar mereka dapat meningkatkan kemampuannya untuk mengembangkan kemampuan mengelola pembelajaran dengan lebih baik. Menurut Sahertian (2002) menyebutkan bahwa tujuan supervisi merupakan pemberian layanan dan bantuan untuk mengembangkan situasi belajar-mengajar yang dilakukan guru di kelas. Tujuan dari diadakannya supervisi terdiri dari tujuan umum dan tujuan khusus yaitu diantaranya memberikan bantuan teknis dan bimbingan kepada guru dan staf sekolah yang lain agar personil tersebut mampu meningkatkan kualitas kinerjanya, terutama dalam melaksanakan tugas, yaitu melaksanakan proses pembelajaran dan meningkatkan kualitas pengelolaan sekolah, khususnya dalam mendukung terciptanya suasana kerja yang optimal, yang selanjutnya siswa dapat mencapai prestasi belajar sebagaimana diharapkan.

Motivasi merupakan suatu dorongan bagi individu baik dalam diri maupun dari luar yang dapat mempengaruhi etos kerja atau kualitas kerja individu tersebut. Menurut Anoraga (2006) menjelaskan bahwa motivasi adalah sebagai kebutuhan yang mendorong perbuatan ke arah suatu tujuan tertentu. Motivasi kerja adalah sesuatu yang menimbulkan semangat atau dorongan kerja. Oleh sebab itu, kuat dan lemahnya motivasi kerja seorang tenaga kerja ikut menentukan besar kecilnya prestasinya. Menurut Indah dalam Lian (2021) motivasi adalah motivasi atau keinginan untuk memperoleh sesuatu dari dalam hati untuk membuktikannya dalam bentuk prestasi belajar.

Menurut Sumadi (2001) motivasi terdiri dari dua yang pertama yaitu motivasi bawaan adalah motivasi yang dibawa sejak lahir, jadi motivasi tersebut ada pada diri seseorang tanpa dipelajari. Yang kedua, motivasi 
yang dipelajari yaitu motivasi yang timbul karena dipelajari oleh seorang individu misalnya dorongan untuk belajar suatu cabang ilmu pengetahuan. Selanjutnya Woodworth (2001) menjelaskan bahwa ciri-ciri motivasi sesuai dengan pembagiannya yaitu terdiri dari 1) motivasi jasmaniah misalnya: refleks, insting otomatis, nafsu. Sedangkan motivasi rohaniah yaitu kemauan. 2) motivasi intrinsik dan ekstrinsik Motivasi intrinsik adalah motif-motif yang aktif tanpa perlu dirangsang dari luar, karena dalam diri setiap individu sudah ada dorongan untuk melakukan sesuatu. Misalnya seseorang belajar, memang benar-benar ingin mengetahui segala sesuatunya, bukan karena ingin pujian/ganjaran. Motivasi ekstrinsik adalah motif-motif yang aktif dan berfungsinya karena adanya perangsang dari luar. Sebagai contoh seseorang itu belajar, karena tahu besok paginya akan ujian dengan harapan mendapatkan nilai baik, sehingga akan dapat pujian oleh pacarnya atau temannya.

Menurut Suryosubroto (2002) menjelaskan bahwa kinerja guru adalah kesanggupan atau kecakapan para guru dalam menciptakan suasana komunikasi yang edukatif antara guru dan siswa yang mencakup suasana kognitif, efektif, dan psikomotorik sebagai uapaya untuk mempelajari sesuatu berdasarkan perencanaan sampai dengan tahap evaluasi dan tindak lanjut agar mencapai tujuan pengajaran. Berdasarkan Peraturan Menteri Pendidikan Nasional Republik Indoesia Nomor 16 Tahun 2007 tentang Standar Kualifikasi Akademik dan Kompetensi Guru. Dijelaskan bahwa Standar Kualifikasi Akademik dan Kompetensi Guru dikembangkan secara utuh dari 4 kompetensi utama yaitu: 1) kompetensi padagogik, 2) kompetensi kepribadian, 3) kompetensi sosial dan 4) kompetensi profesional. Keempat kompetensi tersebut terintegrasi dalam kinerja guru.

Banyak faktor yang bisa mempengaruhi kinerja seseorang mulai dari dirinya sendiri ataupun dari orang lain. Menurut Malthis dan Jackson (2006) terdapat faktor-faktor yang mempengaruhi kinerja guru diantaranya a) kemampuan mereka, b) motivasi, c) dukungan yang diterima, d) keberadaan pekerjaan yang mereka lakukan, e) hubungan guru dengan organisasi.

\section{METODE PENELITIAN}

Penelitian ini dilakukan dengan pendekatan kuantitatif. Subyek penelitian adalah guru dan kepala sekolah sedangkan obyek penelitian adalah supervisi kepala sekolah dan motivasi kerja guru di SMP Negeri Sekecamatan Prabumulih Barat. Penelitian survey dimaksudkan untuk memperoleh gambaran umum mengenai supervisi kepala sekolah dan motivasi kerja guru terhadap kinerja guru di SMP Negeri Sekecamatan Prabumulih Barat.

Populasi adalah sekumpulan individu yang dijadikan sebagai pokok bahasan yang akan dikaji dalam penelitian dengan jumlah yang sesuai dengan kapasitas yang memenuhi syarat sebagai objek penelitian. Sugiyono (2017) menyebutkan bahwa populasi adalah wilayah generalisasi yang terdiri atas objek/subjek yang mempunyai kualitas dan karakteristik tertentu yang ditetapkan oleh peneliti untuk dipelajari dan kemudian ditarik kesimpulan. Populasi dalam penelitian ini yaitu kepala sekolah dan seluruh guru di SMP Negeri Se-kecamatan Prabumulih Barat. Jumlah populasi sebanyak 134 dan sampel 104 guru, sisanya 30 orang guru untuk uji coba penelitian. Sampel dalam penelitian diambil guru-guru yang sudah memiliki pengalaman mangajar di atas 2 Tahun dan berpendidikan S1 dalam penelitian ini memilih guru yang memiliki pengalaman 2 Tahun ke atas karena para guru tersebut sudah memiliki pengalaman akan supervisi dan memiliki loyalitas kerja. Untuk mendapatkan pendapat serta penilain terhadap kinerja guru.

Dalam penelitian sampel yang digunakan yaitu kepala sekolah dan guru SMP Negeri Sekecamatan Prabumulih Barat yang memiliki pengalaman 2 Tahun mengajar. Sugiyono (2016: 84) menjelaskan bahwa sampel jenuh merupakan teknik penentuan sampel bila anggota populasi digunakan sebagai sampel. Kemudian untuk lebih jelas jumlah populasi dan sampel dapat dilihat dalam tabel 1.

Tabel 1. Populasi dan Sampel Penelitian

\begin{tabular}{|l|l|c|}
\hline No & Sekolah & Populasi (Orang) \\
\hline 1 & SMPN 4 Prabumulih & 71 \\
\hline 2 & SMPN 9 Prabumulih & 63 \\
\hline Jumlah & 134 \\
\hline
\end{tabular}

\section{HASIL DAN PEMBAHASAN}

\section{Pengaruh Supervisi Kepala Sekolah (X1), terhadap Kinerja Guru (Y)}

Berdasarkan hasil uji hipotesis yang dilakukan oleh peneliti bahwa terdapat pengaruh positif dan signifikan antara Supervisi Kepala Sekolah terhadap Kinerja Guru di SMP Negeri se-Kecamatan Prabumulih Barat. Hal ini dibuktikan dari nilai hasil pengujian hipotesis diperoleh pula nilai probabilitas $(0,000)$ lebih kecil dari nilai $f t(0,05)$, selain itu, untuk nilai thitung sebesar 5,167 dengan $t(0,05)(1,289)$ Dengan demikian nilai thitung $(5,167)$ lebih besar dari nilai tTabel $(1,289)$ sehingga dapat disimpulkan bahwa Ha diterima. Artinya, terdapat pengaruh supervisi kepala sekolah terhadap kinerja guru di SMP Negeri Se-Kecamatan Prabumulih 
Barat. Besarnya pengaruh supervisi kepala sekolah terhadap kinerja guru di SMP Negeri Se Kecamatan Prabumulih Barat sebesar 52,6\% sisanya $47,4 \%$ dipengaruhi oleh faktor lain yang bukan menjadi variabel dalam penelitian ini.

Berdasarkan uraian di atas, maka dapat disimpulkan bahwa semakin baik supervisi kepala sekolah, maka semakin baik kinerja guru di SMP Negeri Kecamatan Prabumulih Barat, dan sebaliknya semakin rendahnya supervisi kepala sekolah, maka semakin kurang baik kinerja guru di SMP Negeri Kecamatan Prabumulih Barat.

\section{Pengaruh Motivasi Kerja (X2), terhadap Kinerja Guru (Y)}

Berdasarkan hasil uji hipotesis yang dilakukan oleh peneliti bahwa terdapat pengaruh positif dan signifikan antara motivasi kerja guru terhadap Kinerja Guru di SMP Negeri se-Kecamatan Prabumulih Barat. Hal ini dibuktikan dari nilai hasil pengujian hipotesis diperoleh pula nilai probabilitas $(0,000)$ lebih kecil dari nilai $f t(0,05)$, selain itu, untuk nilai thitung sebesar 1,657 dengan $t(0,05)(1,289)$ Dengan demikian nilai thitung $(1,657)$ lebih besar dari nilai ttabel $(1,289)$ sehingga dapat disimpulkan bahwa Ha diterima. Artinya, terdapat pengaruh motivasi kerja guru terhadap kinerja guru di SMP Negeri Se- Kecamatan Prabumulih Barat Besarnya pengaruh motivasi kerja guru terhadap kinerja guru di SMP Negeri Se-Kecamatan Prabumulih Barat sebesar $46,2 \%$ sisanya $53,8 \%$ dipengaruhi oleh faktor lain yang bukan menjadi variabel dalam penelitian ini.

Berdasarkan uraian di atas, maka dapat disimpulkan bahwa semakin baik motivasi kerja guru, maka semakin baik kinerja guru di SMP Negeri Kecamatan Prabumulih Barat, dan sebaliknya semakin rendahnya motivasi kerja guru, maka semakin kurang baik kinerja guru di SMP Negeri Kecamatan Prabumulih Barat.

\section{Pengaruh Supervisi Kepala Sekolah (X1), Motivasi Kerja Guru (X2) terhadap Kinerja Guru (Y)}

Berdasarkan hasil penelitian hasil penelitian menunjukkan bahwa terdapat hubungan positif dan signifikan antara supervisi kepala sekolah dan motivasi kerja guru secara bersama-sama terhadap kinerja guru, hal ini dibuktikan dari nilai hasil pengujian hipotesis diperoleh nilai probabilitas $(0,000)$ lebih kecil dari nilai $\alpha(0,05)$, selain itu, diketahui Fhitung $=170,965$ dan Ftabel $=3,08$ dimana Fhitung $>$ Ftabel yang berarti Ha diterima atau dengan kata lain ada pengaruh supervisi kepala sekolah dan motivasi kerja guru secara bersama-sama terhadap kinerja guru. Untuk mengetahui besarnya pengaruh supervisi kepala sekolah dan motivasi kerja guru secara bersama-sama terhadap kinerja guru. Besarnya pengaruh supervisi kepala sekolah dan motivasi kerja guru secara bersama-sama terhadap kinerja guru di SMP Negeri se-Kecamatan Prabumulih Barat, sebesar $58,5 \%$ sisanya $41,5 \%$ dipengaruhi oleh faktor lainnya yang tidak termaksud variable variabel pada penelitian ini.

Berdasarkan uraian di atas dapat disimpulkan bahwa faktor yang mempengaruhi kinerja guru dalam berkerja yaitu supervisi kepala sekolah mempunyai pengaruh yang sangat besar terhadap kinerja guru karena dengan adanya supervisi kepala sekolah yang baik dilakukan oleh kepala sekolah akan dapat memingkakan kinerja guru akan juah lebih baik, serta adanya motivasi kerja guru dalam melaksanakan tugasnya akan jauh lebih baik kinerja guru tersebut. Sehingga dengan ini bahwa supervisi kepala sekolah dan motivasi kerja guru berpengaruh kapada kinerja guru dalam berkerja, dimana hasil penelitian ini juga menunjukkan bahwa supervisi kepala sekolah dan motivasi kerja guru memberikan pengaruh sebesar 58,5\% pada kinerja guru. Dengan demikian supervisi kepala sekolah dan motivasi kerja guru secara bersama-sama terhadap kinerja. Semakin baik supervisi kepala sekolah dan motivasi kerja guru, maka semakin baik kinerja guru di SMP Negeri se-Kecamatan Prabumulih

\section{SIMPULAN}

Supervisi kepala sekolah memiliki pengaruh yang positif dan signifikan terhadap kinerja guru di sekolah. Motivasi kerja guru memiliki pengaruh yang positif dan signifikan terhadap kinerjanya. Secara simultan atau bersama-sama kedua variabel bebas (supervisi kepala sekolah dan motivasi kerja guru) memiliki pengaruh terhadap variabel terikat (kinerja guru).

\section{UCAPAN TERIMA KASIH}

Ucapan terima kasih diberikan kepada Kepala SMP Negeri 4 Prabumulih dan Rektor Universitas PGRI Palembang yang telah membantu dalam penyelesaian jurnal ini. Kemudian terima kasih juga kepada temanteman dan semua pihak yang telah membantu penulisan dan penerbitan jurnal ini.

\section{DAFTAR PUSTAKA}

Anoraga, P. (2006). Psikologi Kerja. Jakarta: PT. Rineka Cipta.

Fitria, H. (2020). Implementasi Supervisi Akademik Dalam Meningkatkan Kinerja Guru. Jurnal Manajemen, Kepemimpinan, dan Supervisi Pendidikan, Volume 5, No. 2, Juli-Desember 2020 
Harapan, E. (2020). Pengaruh Profesionalisme Guru dan Supervisi Kepala Sekolah Terhadap Kinerja Guru, Jurnal Manajemen, Kepemimpinan, dan Supervisi Pendidikan, Volume 5, No. 2, Juli-Desember 2020

Lian, B. (2020). Pengaruh Kepemimpinan Dan Motivasi Kerja Guru Terhadap Disiplin Kerja, Jurnal Manajemen, Kepemimpinan, dan Supervisi Pendidikan, Volume 6, No. 1, Januari-Juni 2021

Mathis, R. L. \& Jackson, J. H. (2006). Human Resource Management: Manajemen Sumber Daya Manusia. Terjemahan Dian Angelia. Jakarta: Salemba Empat.

Mulyasa. (2007). Standar Kompetensi dan Sertifikasi Guru. Bandung: PT Remaja Rosdakarya

Peraturan Menteri Pendidikan Nasional Republik Indonesia Nomor 16 tahun 2007 tentang Standar Kualifikasi Akademik dan Kompetensi Guru

Sahertian, P. A. (2002). Konsep Dasar dan Teknik Supervisi Pendidikan dalam rangka Pengembangan Sumber Daya Manusia. Jakarta. Rineka Cipta.

Saondi, O., \& Suherman, A. (2010). Etika Profesi Keguruan. Bandung: PT Refika Aditama

Sugiyono. (2016). Statistika untuk Penelitian. Bandung: Alfabeta.

Sumadi. (2001). Metodologi Penelitian. Jakarta: Rajawali Pers.

Suryosubroto. (2002). Proses Belajar Mengajar Di Sekolah. Jakarta: Rineka Cipta

Undang-Undang Republik Indonesia Nomor 20 Tahun 2003 tentang Sistem Pendidikan Nasional.

Wahyudi. (2009). Kepemimpinan Kepala Sekolah Dalam Organisasi Pembelajaran. Bandung: Alfabeta.

Wilis. (2001). Teori-teori Belajar. Jakarta: Erlangga.

Woodworth. (2001). Bimbingan dan Penyuluhan di Sekolah. Yogyakarta: Andi Offset. 